Jurnal Kesehatan Hesti Wira Sakti vol 8 No 12020

ISSN 2302-4283 (print)

ISSN 2580-9571 (online)

Online di https://jurnal.poltekkes-soepraoen.ac.id

DOI: $10.47794 /$ jkhws

\title{
ANALISIS FAKTOR IBU YANG MEMPENGARUHI PENCAPAIAN PERAN IBU PRIMIPARA DI BPM A KOTA MALANG
}

\author{
Nunung Ernawati ${ }^{1}$ \\ ${ }^{1}$ Prodi Keperawatan Institut Teknologi Sains dan Kesehatan RS Dr. Soepraoen Malang \\ (Korespondensi: nunungerna@gmail.com)
}

\begin{abstract}
ABSTRAK
Latarbelakang menerima peran baru sebagai ibu membutuhkan adaptasi fisik dan psikologis, karena perkembangan identitas peran ibu sangat dipengaruhi oleh banyak faktor, hambatan penerimaan peran ibu berdampak pada kemampuan ibu merawat diri dan bayinya. Tujuan penelitian menganalisis faktor yang berpengaruh pada pencapaian peran ibu primipara. Metode The Study was correlational research design, population of all primiparous mothers is 20 people/month. Samples that meet the inclusion criteria are 15 people. The instrument used a modified questionnaire from the New Parent Questionnaire from Kim Green, RN, ICCE. Data collection with the help of enumerators met with respondents 1-2 days post partum. The data were analyzed by logistic regression test with a significance level of $=0.05$.

Hasil menunjukan faktor usia mempengaruhi pencapaian peran ibu primipara hampir seluruhnya dewasa awal sejumlah 9 responden (60\%), faktor persepsi ibu positif 14 responden ( 93,3\%), konsep diri ibu positif sejumlah 14 responden (93,3\%), sikap ibu positif sejumlah 14 responden (93,3\%). Berdasarkan hasil uji logistic regresi dengan uji signifikansi parsial (uji Wald) didapatkan p value $0,000<\alpha=0,05$ hal ini menunjukan ada pengaruh antara faktor usia, persepsi, sikap dan konsep diri terhadap pencapaian peran ibu primipara. Prevalence ratio atau $\operatorname{Exp}(\mathrm{B})$ konsep diri $0,000=0 \%$ diartikan konsep diri ibu tidak memiliki peluang untuk mempengaruhi pencapaian peran ibu. Kesimpulan pencapaian peran ibu membutuhkan persiapan diri seoptimal untuk menerima dan menyambut kelahiran bayi, perlu ditanamkan sikap dan penilaian diri yang positif pada ibu. Keluarga dan petugas kesehatan perlu memberikan dukungan melalui edukasi, sharing pengalaman untuk menumbuhkan kepercayaan diri ibu primipara
\end{abstract}

Kata Kunci: pencapaian peran, ibu,primipara

\begin{abstract}
Introduction accepting a new role as a mother requires physical and psychological adaptation, because the development of mother's role identity is strongly influenced by many factors, barriers to acceptance of the mother's role have an impact on the mother's ability to care for herself and her baby. The purpose of the study is to analyze the factors that influence the achievement of the role of primiparous mothers Methode Research desain is correlational study and the population of study are primiparous post partum mothers are an average 20/month. Sample of study a half of primiparous post partum mothers in BPM A Malang city with inclussion criteria are 15 people. Instrument are used interview, modification quesionnaire from New Parent Quesionnaire Kim Green, RN, ICCE. Analyze data are used univariate and multiavariate are logistic regression with level of significancy $\alpha=0,05$. The study was conducted in February until August 2018. Result shows that the age factor affects the achievement of the role of primiparous mothers almost entirely in early adulthood as many as 9 respondents $(60 \%)$,
\end{abstract}


Jurnal Kesehatan Hesti Wira Sakti vol 8 No 12020

ISSN 2302-4283 (print)

ISSN 2580-9571 (online)

Online di https://jurnal.poltekkes-soepraoen.ac.id

DOI: $10.47794 /$ jkhws

positive mother perception factors 14 respondents (93.3\%), positive mother self-concept as many as 14 respondents (93.3\%), positive mother attitudes a total of 14 respondents $(93.3 \%)$. Based on the results of the logistic regression test with a partial significance test (Wald's test) obtained p value $0.000<=$ 0.05 this shows that there is an influence between factors of age, perception, attitude and self-concept on the achievement of the role of primiparous mothers. Prevalence ratio or Exp (B) self-concept $0.000=0 \%$ means that the mother's self-concept has no opportunity to influence the achievement of the mother's role. Conclusion the achievement of the mother's role requires optimal self-preparation to receive and welcome the birth of a baby, it is necessary to instill a positive attitude and self-assessment in the mother. Families and health workers need to provide support through education, sharing experiences to grow the confidence of primiparous mothers

Keyword: role attainment, mothers, primiparous

\section{PENDAHULUAN}

Menjadi seorang ibu merupakan suatu perubahan pada perempuan baik perubahan status maupun peran (Indriastuti, 2015.) Pencapaian peran ibu sebagai suatu proses dimana seorang ibu dapat mencapai kemampuannya dalam menjalankan perannya sebagai ibu, mengintegrasikan perilaku keibuannya sampai mereka menemukan peran baru dimana mereka mencapai kepercayaan diri, dan keselarasan dengan identitas barunya. Pencapaian peran ibu (maternal role attainment) adalah suatu proses pengembangan dan interaksional dimana setiap saat ketika ibu menyentuh bayinya akan menciptakan kemampuan mengasuh dan merawat termasuk membentuk peran dan menunjukkan kepuasan dan kesenangan menikmati perannya tersebut. Bagi ibu primipara pencapaian peran baru sebagai ibu sangat membutuhkan dukungan yang lebih baik dari suami maupun dari keluarga. perubahan ini perlu dipersiapkan sejak awal, jika tidak maka ibu dapat mengalami kecemasan yang berlebihan terkait perubahan suasana hati, perasaan tidak mampu merawat diri, kurang percaya diri dalam merawat bayinya serta perubahan yang terjadi pada dirinya setelah melahirkan, hal ini sering disebut sebagai baby blues syndrome, Sehingga untuk mengantisipasinya setiap ibu nifas sangat membutuhkan pendampingan baik dari petugas maupun keluarga dalam melalui tahap penyesuaian peran

Angka cakupan pertolongan persalinan oleh tenaga kesehatan di Jawa Timur tahun 2010 adalah $82,2 \%$ dan tahun 2012 turun menjadi 63,8\% untuk wilayah kota dan 53\% untuk wilayah desa, tahun 2013 sebesar 87,1\% (SDKI 2007, SDKI 2012,Riskesdas 2013). Berdasarkan hasil penelitian Kirana, 2015, hasil penelitian 
tentang kejadian Post Partum Blues bahwa perempuan yang melahirkan mengalami Post Partum Blues diIndonesia sebanyak 50-70\%.

Pengalaman melahirkan memberi kontribusi besar dalam pembentukan peran sebagai ibu. Masa ini disebut sebagai masa peralihan atau transisi. Menurut Scumacher dan Meleis (2009) masa peralihan mengalami perubahan besar antara lain perubahan identitas, peran, hubungan, kemampuan dan perilaku. Kondisi yang mempengaruhi pengalaman pada masa peralihan adalah pemahaman, harapan, tingkat pengetahuan, lingkungan, tingkat perencanaan, serta kondisi fisik dan emosional. Masa pasca persalinan merupakan " awal keluarga baru” bagi keluarga muda sehingga mereka perlu adaptasi dengan peran barunya. Tanggungjawab keluarga bertambah dengan hadirnya bayi yang baru lahir. Komponen psikologis dalam proses adaptasi adalah pengalaman awal orang tua dengan cinta kasih, penerimaan figur sebagai orang tua, memiliki rasa peraya diri dan perhatian terhadap perkembangan bayi. Nilai dan keyakinan ini mencakup sikap terhadap kelembutan dan memberi perhatian terhadap kebutuhan bayi
(Kasdu, 2009) . Mercer dalam Irianti 2010 mengatakan ada beberapa faktor yang mempengaruhi pencapaian peran ibu antara lain usia ibu, konsep diri ibu, kepercayaan diri ibu dalam merawat bayinya, status kesehatan ibu dan bayi, kecemasan dan ada tidaknya depresi. Pencapaian peran yang terhambat dapat menimbulkan dampak ke ibu dan bayinya, keputusaan ibu semakin bertambah dan dapat menimbulkan depresi post partum, sehingga status kesehatan ibu nifas menurun, ibu sulit memberikan ASI ke bayinya dan pada akhirnya bayi secara fisik kurang terawat dan secara psikologis bayi akan merasakan ketidaknyamanan di lingkungan tempat tinggalnya. Perhatian dan dorongan anggota keluarga lainnya merupakan dukungan positif bagi ibu untuk memulai "penerimaan peran baru"sebagai ibu baru. Upaya yang dibutuhkan adalah pendekatan yang komprehensif, pelayana petugas yang kompeten termasuk peran dalam mengekspresikan kepuasan dan penghargaan peran. Seharusnya pencapaian peran ibu dimulai sejak awal kehamilan ibu sampai 6 bulan setelah melahirkan, ibu dimotivasi untuk ikut kelas ibu hamil/prenatal, ibu nifas dan konseling ASI agar ibu mempunyai rasa 
Jurnal Kesehatan Hesti Wira Sakti vol 8 No 12020

ISSN 2302-4283 (print)

ISSN 2580-9571 (online)

Online di https://jurnal.poltekkes-soepraoen.ac.id

DOI: $10.47794 /$ jkhws

percaya diri yang kuat dalam merawat bayinya, disamping itu dibutuhkan dukungan dari suami dan anggota keluarga yang lain, sehingga dapat menumbuhkan rasa kepercayaan diri ibu untuk siap menerima dan merawat bayinya.

Tujuan penelitian ini adalah menganalisis faktor- faktor yang mempengaruhi pencapaian peran ibu primipara di BPM A Kota Malang.

\section{METODE PENELITIAN}

Penelitian ini menggunakan rancangan desain penelitian korelasional dengan pendekatan cross sectional. Populasi dalam penelitian ini adalah semua ibu post partum primipara yang baru melahirkan sejumlah 20 orang/ bulan. Sampel dalam penelitian adalah sebagian ibu post partum primipara diklinik BPM A Kota Malang yang memenuhi kriteria inkluksi sejumlah 15 orang. Instrumen yang digunakan adalah kuesioner modifikasi dari New Parent Quesionnaire dari Kim Green, RN, ICCE. Data hasil akan dilakukan analisis univariat dan multivariat (uji logistic regresi) level signifikansi $\alpha=0,05$ level. Penelitian ini dilakukan pada bulan April s/d Agustus 2018.
Penelitian ini menggunakan desain penelitian korelasional . Populasi dalam penelitian ini adalah semua ibu post partum primipara yang baru melahirkan sejumlah 20 orang/ bulan. Sampel dalam penelitian adalah sebagian ibu post partum primipara diklinik BPM A Kota Malang yang memenuhi kriteria inkluksi sejumlah 15 orang. Instrumen yang digunakan adalah wawancara dan kuesioner modifikasi dari New Parent Quesionnaire dari Kim Green, RN, ICCE. Data hasil akan dilakukan analisis univariat dan multivariat (uji logistic regresi) level signifikansi $\alpha=0,05$ level. Penelitian ini dilakukan pada bulan Pebruari s/d Agustus 2018. Untuk melindungi hak-hak responden penelitian ini menerapkan prinsip etika penelitian anonimity, justice dan confidentiality.

\section{HASIL PENELITIAN}

Berdasarkan hasil penelitian didapatkan bahwa karakteristik responden didapatkan data bahwa kategori usia mayoritas adalah usia 26-30 tahun sejumlah 9 orang (60\%), jenis kelamin responden seluruhnya adalah perempuan 15 orang (100\%), tingkat pendidikan mayoritas lulus SLTA sejumlah 7 orang $(46,7 \%)$, mayoritas responden tidak bekerja atau sebagai ibu rumah tangga sejumlah 12 (80\%), pendapatan keluarga 
Jurnal Kesehatan Hesti Wira Sakti vol 8 No 12020

ISSN 2302-4283 (print)

ISSN 2580-9571 (online)

Online di https://jurnal.poltekkes-soepraoen.ac.id

DOI: $10.47794 /$ jkhws

mayoritas berkisar antara Rp.2.000.000 s/d

Rp. 3.000.000 11 orang (73,3\%) dan

budaya yang di anut keluarga terkait perawatan ibu nifas adalah minum jamu atau ramuan tertentu sejumlah 11 orang ( $73.3 \%)$

Sedangkan data khusus variabel penelitian didapatkan data sebagai berikut:

Tabel 1.1 Distribusi Frekuensi Faktor-Faktor Yang Mempengaruhi Pencapaian Peran Ibu Primipara di BPM Bulan April-Agustus 2018

\begin{tabular}{|c|c|c|c|}
\hline No & Variabel & $\mathbf{f}$ & $\%$ \\
\hline \multirow[t]{4}{*}{1.} & Faktor Usia & & \\
\hline & Remaja akhir & 5 & 33,3 \\
\hline & Dewasa awal & 9 & 60 \\
\hline & Dewasa akhir & 1 & 6,7 \\
\hline \multicolumn{2}{|c|}{ Total } & 15 & 100 \\
\hline \multirow[t]{3}{*}{2.} & Faktor Persepsi Ibu & & \\
\hline & Positif & 14 & 93,3 \\
\hline & Negatif & 1 & 6,7 \\
\hline \multicolumn{2}{|c|}{ Total } & 15 & 100 \\
\hline \multirow[t]{3}{*}{3.} & Faktor Sikap Ibu & & \\
\hline & Positif & 14 & 93,3 \\
\hline & Negatif & 1 & 6,7 \\
\hline \multicolumn{2}{|c|}{ Total } & 15 & 100 \\
\hline \multirow[t]{3}{*}{4.} & Faktor Konsep Diri & & \\
\hline & Positif & 14 & 93,3 \\
\hline & Negatif & 1 & 6,7 \\
\hline \multicolumn{2}{|c|}{ Total } & 15 & 100 \\
\hline \multirow[t]{3}{*}{5.} & Faktor Kecemasan I & & \\
\hline & Cemas & 8 & 53,3 \\
\hline & Tidak cemas & 7 & 46,7 \\
\hline \multicolumn{2}{|c|}{ Total } & 15 & 100 \\
\hline \multirow[t]{3}{*}{6.} & Faktor Dukungan $\mathrm{S}$ & & \\
\hline & Positif & 7 & 46,7 \\
\hline & Negatif & 8 & 53,3 \\
\hline Total & & 15 & 100 \\
\hline
\end{tabular}

Berdasarkan tabel distribusi frekuensi diatas didapatkan bahwa faktor yang mendukung pencapaian peran ibu adalah; usia ibu 60\%, persepsi ibu postif 93,3\%, sikap positif 93,3\%, konsep diri positif 93,3\%, dan faktor yang kurang mendukung pencapaian ibu adalah ibu mengalami kecemasan $53.3 \%$ dan dukungan sosial negatif $53,3 \%$.

Berdasarkan hasil uji analisis multivariat regresi logistic dengan level signifikansi $\alpha$ 0,05 untuk melihat interaksi antar faktor didapatkan hasil sebagai berikut:

Hasil uji negelkerke $\mathrm{R}^{2}$ dihasilkan $49,7 \%$, maka disimpulkan bahwa varabel prediktor (seluruh faktor ibu) mempengaruhi variabel respon (pencapaian peran ibu) sebesar $49,7 \%$ dan sisanya dipengaruhi oleh variabel lain. Hasil uji Hosmer dan lemeslow $\mathrm{p}$ value $=0,557$ artinya tidak terdapat multikolinearitas. Uji signifikansi parsial (uji Wald) didapatkan $\mathrm{p}$ value $0,000<\alpha=0,05$ pada faktor usia, persepsi, sikap dan konsep diri. Hal ini bermakna bahwa ada pengaruh antara faktor usia, persepsi, sikap dan konsep diri terhadap pencapaian peran ibu primipara.

Prevalence ratio atau Exp (B) konsep diri $=0,000=0 \%$ maka dapat diartikan bahwa konsep diri ibu tidak memiliki peluang untuk mempengaruhi pencapaian peran ibu primipara. Sedangkan faktor usia, persepsi dan sikap memiliki nilai prevalence ratio $>1$ maka dapat diartikan bahwa faktor usia, persepsi dan sikap ibu merupakan faktor resiko untuk 
Jurnal Kesehatan Hesti Wira Sakti vol 8 No 12020

ISSN 2302-4283 (print)

ISSN 2580-9571 (online)

Online di https://jurnal.poltekkes-soepraoen.ac.id

DOI: $10.47794 / \mathrm{jkhws}$

mempengaruhi pencapaian peran ibu primipara.

\section{PEMBAHASAN}

Berdasarkan hasil uji analisis didapatkan bahwa terdapat pengaruh faktor usia, persepsi, dan sikap ibu terhadap pencapaian peran ibu primipara dengan pencapaian peran ibu primipara.

Hal ini didukung oleh data usia responden masuk dalam kategori usia remaja akhir sejumlah 5 responden (33,3\%), dewasa awal lebih dari separuh 9 responden ( 60\%) dan dewasa akhir sejumlah 1 responden ( $6,7 \%$ ) hal ini sesuai dengan teori yang menyatakan bahwa usia ibu berefek nyata dalam transisi menjadi orang tua. Transisi menjadi orang tua mungkin sulit bagi orang tua dengan usia remaja, oleh karena remaja seringkali mengalami kesulitan dalam memenuhi kebutuhan tahap perkembangannya, menghadapi tugastugas perkembangan menjadi orang tua. Beberapa orang tua muda mengalami kesulitan menerima perubahan gambaran diri dan menyesuaikan dengan peran baru terkait tanggungjawab perawatan bayinya. Pencapaian peran menjadi ibu membutuhkan kematangan usia ibu, supaya ibu dapat dengan mudah menyesuaikan diri baik fisik maupun psikologis dalam menjalani tugas dan perkembangan menjadi ibu yang memiliki tanggungjawab merawat bayi.

Hasil penelitian diatas juga didukung oleh data hasil penelitian yaitu sikap dan persepsi dimana masing -masing faktor hampir seluruhnya 14 responden ( 93,9\%) memiliki sikap dan persepsi positif

Persepsi dapat didefinisikan sebagai proses penilaian individu yang dihasilkan oleh adanyan penginderaan dan diorganisasikan dan menafsirkan informasi sensoris guna mendapatkan gambaran dan penilaian tentang segala sesuatu. Sedangkan sikap merupakan kecenderungan pikiran, perasaan untuk mengenal aspek-aspek tertentu terhadap objek yang diamati. Objek dalam hal ini adalah peran menjadi ibu. Menurut Lowdermilk 2013 menyatakan terdapat tiga fase pencapaian peran ibu, dimana ibu akan menyesuaikan dengan peran baru tersebut. Hal ini sesuai dengan teori Mercer (2004) berpendapat bahwa menjadi seorang ibu menyiratkan lebih dari sekadar pencapaian peran namun mencakup pencapaian keahlian baru, meningkatkan rasa percaya diri dalam melakukan perawatan anaknya. Transisi menjadi ibu membutuhkan penyesuaian dari ibu dan keluarganya. Responsivitas ibu merupakan faktor 
dominan dalam hubungan ibu-bayi. Hal ini dapat didefinisikan sebagai kualitas perilaku sensitif ibu yang didasari oleh kewaspadaan, persepsi dan responsivitasnya terhadap isyarat dan perilaku bayi. Sensitivitas seorang ibu bersifat dinamis dan berkembang dari waktu ke waktu dalam sebuah hubungan timbal balik, memberi dan menerima dengan bayinya.

Menurut Lodermilk, 2013 menyebutkan bahwa terdapat 2 proses sosial dalam menghadapi transisi menjadi ibu, proses utama adalah keterlibatan yaitu membuat komitmen untuk menjadi seorang ibu, aktif merawat anaknya, dan merasakan kehadirannya. Proses kedua adalah ibu merasakan dirinya sebagi seorang ibu, yang mengarahkan pada pertumbuhan dan transformasi. Selama proses tersebut seorang ibu baru harus belajar bagaimana menjadi seorang ibu serta beradaptasi terhadap perubahan hubungannya dengan pasangan, keluarga dan teman-temannya.

Persepsi dan sikap merupakan komponen pembentuk perilaku individu, persepsi dan sikap yang positif sangat penting dalam membentuk perilaku seorang ibu yang baru saja memiliki anak. Menjadi ibu merupakan transformasi peran yang luarbiasa baik secara fisik maupun psikologis, memiliki bayi untuk pertama kalinya bagi sebagian besar wanita dapat menjadi tekanan psikologis tersendiri, sehingga seorang ibu perlu beradaptasi lebih awal untuk mempelajarai perubahanperubahan yang akan terjadi saat memiliki bayi baru lahir, ibu perlu belajar tentang segala sesuatu terkait perawatan bayi, ibu juga harus siap dengan perubahan sosial baik dengan teman, keluarga besar maupun dengan pasangan. Sehingga diperlukan sikap dan persepsi yang positif untuk dapat memudahkan ibu dalam menerima peran baru dan beradaptasi dengan peran dan tanggungjawab untuk merawat anaknya.

\section{Simpulan dan Saran}

Berdasarkan hasil penelitian dapat disimpulkan sebagai berikut:

Terdapat pengaruh faktor ibu yang mempengaruhi pencapaian peran ibu primipara di BPM A Kota Malang yaitu usia, persepsi, sikap dan konsep diri dengan $p$ value 0,000 .

Faktor usia, persepsi dan sikap ibu primipara memiliki resiko mempengaruhi pencapaian peran ibu dengan nilai Prevalence Ratio $>1$, sedangkan faktor konsep diri memiliki nilai PrevalenceRatio $=0$ sehingga dapat disimpulkan bahwa konsep diri tidak memiliki peluang untuk mempengaruhi pencapaian peran ibu.

Berdasarkan hasil penelitian maka diharapkan petugas kesehatan terutama di BPM A lebih meningkatkan pelayanan berbasis edukasi tentang persiapan menjadi 
orang tua sehingga klien dapat lebih mudah beradaptasi dengan transisi peran yang akan dijalaninya, dan hasil penelitia dapat dijadikan sebagai data awal dan dapat dikembangkan oleh peneliti lain dalam bentuk penelitian dengan metode kualitatif

\section{DAFTAR PUSTAKA}

Dinas Kesehatan Jawa Timur. Profil Kesehatan Provinsi Jawa Timur Tahun 2012.Dinas Kesehatan 2013

Fadlun. Asuhan Kebidanan Patologis. Jakarta: Salemba Medika.2014

Indriyani, Diyan.2013. Keperawatan Maternitas Pada Area Perawatan Antenatal. Yogyakarta: Graha Ilmu.

Indriastuti.Nur. Faktor-Faktor Yang Mempengaruhi Pencapaian Peran Ibu Pada Wanita dengan HIV AIDS di Yogyakarta. Jurnal Mutiara Medika. Volume 15 No 1 Januari 2015

Kirana. Yuke. Hubungan Tingkat Kecemasan Post partum dengan Kejadian Post Partum Blues di Rumah sakit Dustira Cimahi Bandung. Jurnal Ilmu Keperawatan. Volume III. No 1 April 2015

Kurniawan. Anto. dkk. Pengaruh Dukungan Keluarga Terhadap Pencapaian Peran Ibu Primigravida. Di wilayah Kerja PKM Ngaglik Sleman.Jurnal Samudra Ilmu Volume 08 Nomor 01 Januari 2017 Lodermilk, et all, 2013. Keperawatan Maternitas, Mosby. Elsevier, Singapura

Manuaba, Ida Bagus Gde.(2007). Pengantar Kuliah Obstetri. Jakarta: EGC.

Oktaviani. Senti,dkk. Pengaruh Usia Dan Konsep Diri Terhadap Pencapaian Peran Ibu Saat Bayi Usia 0-6 bulan Di desa Bojongsari Kecamatan Bojongsari Kabupaten Purbalingga. Jurnal Ilmiah Kebidanan Bidan
Prada. Volume 5 no 1 Edisi Juni 2014

Santy. Fitri. Pengalaman remaja Putri Single Parent Menjalani Peran Baru sebagai Ibu Di Wilayah Puskesmas Panjang Kota Bandar Lampung. Tesis 2015 